Saudi Journal of Business and Management Studies Abbreviated Key Title: Saudi J Bus Manag Stud ISSN 2415-6663 (Print) |ISSN 2415-6671 (Online) Scholars Middle East Publishers, Dubai, United Arab Emirates Journal homepage: http://scholarsmepub.com/sjbms/

Original Research Article

\title{
Institutional Performance Assessment of Water Supply System
}

\author{
Dr. Anjay Kumar Mishra* \\ Associate Professor, Madan Bhandari Memorial Academy and Pokhara University and Research Coordinator at United Technical College, Chitwan, \\ Nepal
}

\begin{tabular}{ll}
\hline DOI: $10.36348 /$ sjbms.2019.v04i09.002 & | Received: $26.08 .2019 \mid$ Accepted: $12.09 .2019 \mid$ Published: \\
18.09.2019
\end{tabular}

*Corresponding author: Dr. Anjay Kumar Mishra

Email: anjaymishra2000@gmail.com

\section{Abstract}

Most of the water supply systems are managed by water supply users committee. The large numbers of water supply system are not functioning. Dhankuta 7, 8, 9 water supply system was constructed in 1993 and then after it was being operated by Water Supply Users Committee. The water supply system was running 23 years. The performance of the water supply system is under questions. The overall objective of the study was to assess the institutional Performance of Dhankuta 7,8,9 Water Supply System with implementation status of water safety plan. The stratified random sampling method was applied for sampling based on cocharent sampling method. The questionnaire survey focus group discussion, key informant interview, field observation were done to gather primary data as well as published report, journals, research paper, article, progress report were reviewed for secondary data. The institutional performance was analyzed through analysis of functionality index, institutional setup, staff productivity index, capacity of WSUC member and staff separately and the implementation status of water safety plan. Regarding to institutional performance the result shows that the functionality index is $70 \%$, staff productivity index is 36.53 , the individual capacity of WSUC member obtain 8 in institutional management, 7 in both technical knowledge and financial management out of 10. The implementation status of water safety plan shows that it is functioning partially and the consumers are conscious about water quality and more than $50 \%$ prefer boiling before drinking water. It should be enhanced the capacity of WSUC members and staff.

Keywords: Functionality set up institution, productivity, capacity.

Copyright @ 2019: This is an open-access article distributed under the terms of the Creative Commons Attribution license which permits unrestricted use, distribution, and reproduction in any medium for non-commercial use (NonCommercial, or CC-BY-NC) provided the original author and source are credited.

\section{INTRODUCTION Background}

Performance of construction is not as expected in response to resources consumed [1] though the facilities at the construction site for causal workers are compromised to achieve cost and time performance [2]. According to Mishra [3], Salyankot Water Supply Project of Dhadhing District of Nepal is presently functioning with current Functionality index of 58.4\%. For the condition before earthquake it is found that this project was running properly with the functionality index of $71 \%$. According to Mishra [3], the conventional practices used in the design process of a project are best and no other techniques should be followed in the design process is assumption of professional rather than using Value Management. Though according to a survey conducted by Mishra [3] on Existing Class A Construction Companies ware much more capable in terms of HR (Numbers, Experience \& Projects Handled) performance is still a big issue. Water supply is fundamental.

Nepal has achieved the basic level of water supply coverage of $83.59 \%$ whereas the sanitation coverage is $70.28 \%$. Among the project completed the well-functioning project is only $25.4 \%$ and only $8.6 \%$ of the completed project needs reconstruction which shows that the number of project can be made full functional with only major or minor repair and enhancing the capacity of water supply users committee [4]. The emphasis on construction of new water supply 
Anjay Kumar Mishra; Saudi J Bus Manag Stud, Sep 2019; 4(9): 698-707

project is not only the solution to meet the national target but the performance issue of the completed project is also equally important.

In this response, Dhankuta water supply project is the oldest project in Dhankuta town of eastern Nepal. Then after Chuliban water supply project was completed and Lumdang water supply project was done by British Government to meet the water demand of ward no $8 \& 9$ of the town. Due to the cause of source dispute in Lumdang Khola there was scarcity of water in Bazaar area. The population of $8 \& 9$ wards was also increasing creating more demand of water and the consumption of water in military barracks was also high which in cumulating way increasing scarcity so there was lack of adequate water supply in $8 \& 9$ wards of Dhankuta municipality which results in need of separate water supply project in the relevant area.

The community realized the need of separate water supply project in $8 \& 9$ wards leads to the formation of water supply users committee in 1993. There were 7 committee members who purpose the water supply project to run from District Water Supply Office, Dhankuta. The water supply users committee also commits for the community contribution as per Government rules and regulation. The total population of the project area during survey period was 1290. The design population was 1759 . Now 1910 population was being benefitted from this water supply system. The project was constructed in 1993 and the service area at that time was only limited to 8 and 9 wards of Dhankuta municipality and the initial cost of the project is NRs 17, 36, 323 and on improvement some reservoirs are newly constructed at different year. At present the service area also includes ward no.7.

Dhankuta municipality ward no. 8 and 9 lies in Santang and Tekunala respectively was surveyed for water supply initially. In ward no. 8 Danda Tole, Lukma Khola spring was choosen which is nearby village and forward no. 9 chiuribote spring was choosen initially. Now the spring source both lukma khola \& chiuribote are dried up and for 7,8 \& 9 wards only single source Ghatte Khola located at ward no.1 of Dhankuta Municipality is being used. So it is named as Dhankuta 7, 8, 9 water supply system

To gain the national target there should be availability of water supply services to all households which in fact depends upon the functionality of water supply projects. The water supply system should have high level of performance to support the national goal. It is always said institution in developing country is a problem for smooth development. So the Performance assessment of the water supply project in terms of assessment of institutional capacity is significant.

\section{Research Objectives}

The overall objective of this research is to assess the institutional performance and implementation status of Dhankuta 7, 8, 9 water supply systems

\section{LITERATURE REVIEW \\ Operation and Maintenance}

According to Davis and Brikke [5], Operation refers to the everyday running and handling of a water supply and Maintenance refers to the activities required to sustain the water supply in a proper working condition. Operation and Maintenance is a key factor of sustainability in water supply system. Brikke [5] stated that the concern of Operation and Maintenance was neglected in the past. As a result, the credibility of the investments made, the functioning of the services, the well-being of rural populations, and the development of further projects were adversely affected. Though modern water supply system neglected the part of $O \&$ $\mathrm{M}$, there are some strengthens in terms of $\mathrm{O} \& \mathrm{M}$ in community water supply system. For example, a study "Lessons learned from NGO experiences [6] show that there are practices of operation and maintenance, though they have some lacking in terms of management part of water supply system.

Nowadays, there is trend of considering the strength and weak parts of community water supply. As a result, the importance of $\mathrm{O} \& \mathrm{M}$ has gained considerable visibility over the past few years. Policymakers and project designers are now more conscious of the direct links between improved $\mathrm{O} \& \mathrm{M}$ practices and the sustainability of water supply and sanitation services. Similarly, governments, external support agencies and local communities are recognizing the importance of integrating $\mathrm{O} \& \mathrm{M}$ components in all development phases of water supply and sanitation projects, including the planning implementation, management, and monitoring phases [5].

It has been observed that lack of attention to the important aspect of Operation \& Maintenance (O\&M) of water supply schemes in several villages often leads to their dysfunction or deterioration of the useful life of the systems necessitating premature replacement of many components, incurring huge losses. As such even after creating such assets by investing millions of rupees, they failed to provide the proper services effectively to the community for which they have been constructed and became dysfunctional or remained underutilized most of the time. Some of the key issues contributing to the poor Operation \& Maintenance (O\&M) have been identified as follows:

- Lack of finance, equipment, material, and inadequate data on Operation \& Maintenance

- Inappropriate system design; and inadequate Workmanship

- Multiplicity of agencies, overlapping responsibilities

- Inadequate operating staff

- Illegal tapping of water 
- Inadequate training of personnel

- Lesser attraction of maintenance jobs in carrier planning

- Lack of performance evaluation and regular monitoring

- Inadequate emphasis on preventive maintenance

- Lack of O \& M manual

- Lack of real time field information etc.

\section{Performance Evaluation Indicators}

The capacity development program should build a body of evidence allowing independent judgement of how much success the program achieved in accomplishing the learning outcomes. At completion, the program team assesses the achievement of learning outcomes, status of the capacity indicators, and progress toward the development goal [7]. Indicators to assess the changes caused by capacity development program should have been identified while designing the program and defining the outcomes.

Appropriate indicators for assessing capacity development outcomes could be quantitative or qualitative, depending on the nature of the capacity change desired. The process of selecting indicators should always include the consideration of existing data sources and/or the feasibility of collecting the relevant data. Changes in stakeholder perspectives or behaviors are often tracked via surveys whereas changes in the operational efficiency of an organization might be captured through the analysis of existing administrative records. If existing indicators are not sufficient, it is possible to conduct additional data collection and/or analysis after project completion [8].

The World Bank through its International Benchmarking Network for Water and Sanitation Utilities (IBNET) has been involved in water sector monitoring collecting data on utilities performance and has set a global standard for performance assessment of water utilities based on a variety of indicators. IBNET blue book creates a baseline and, at the same time, offers a global vision of the state of the sector in developing countries [4].

IBNET indicators include median and unweighted average values of the performance indicators based on the data and information from more than 4400 utilities from 135 countries. The median values are regarded as a better representation of performance than the average because of its skewness. Specified values of indicators are widely used on assessing and comparing performance of water supply utilities worldwide [4].

\section{National Policies}

\section{Rural Water Supply and Sanitation Policy, 2004}

It is targeted that all of the people will get the facility of water supply and sanitation service within Twelfth Plan Period (2012-2017) as described in Tenth Plan document. Government of Nepal needs to formulate appropriate policy and set guidelines for future programme by giving priority to reliable projects through participatory approach. Water is accepted as a limited source having economic value in this national policy on rural water supply and sanitation. This policy emphasized participatory service delivery, public ownership of assets and initiation of involvement of women.

The objectives of water supply and sanitation services will be to

- $\quad$ Provide safe, accessible and adequate water supply with sanitation facility to all Nepalese people on priority basis especially targeted to the backward people and ethnic groups.

- Reduce water borne disease and its victims in the nation

- Utilize in productive works the time and labor of women, men and children saved from carrying water

The following policies will be adopted to attain the above mentioned objectives

- Cent percent population will get water supply facility by 2017 A.D (2073 B.S) from present basic service level of 71.7 percentage of benefitted population

- Cent percent population will get sanitation facility from the level of sanitation service up to 2017 A.D (B.S 2073)

- Existing water supply system will get massive renovation, rehabilitation, improvement and expansion works as well as increase in the quality of service

- Service development and operation system will be adopted through leadership of local community, which will identify the necessity of the project, its selection, plan formulation, implementation and management by applying participatory approach.

- Capacity of the community will be enhanced for empowerment and management of the water supply system. Public awareness and health education programme will be conducted as an integral part of the programme

- Health education and sanitation activities will be conducted together with water supply and sanitation programme

- Measures will be taken to reduce environmental impacts while implementing water supply projects

- Water supply programme will be conducted in conjunction with other programme related to water resource development, where possible

- Capacity of local bodies, user committees and nongovernmental organization will government's direct involvement in the implementation of water supply and sanitation projects. 
- Projects will be selected for implementation on the basis of projects prepared by the local bodies.

Water safety plan is assumed to be most effective tool for maintaining safe drinking water in society. It ensure regulatory water standard for suitability of water to human health [9].

\section{METHODOLOGY}

\section{Study Area}

Dhankuta 7, 8, 9 water supply lies in Dhankuta municipality of Dhankuta district of eastern Nepal. The design population was 1759 whereas the current population of service area with connection 1910.There is 1453 household with total population 8134 where the expansion of the system is necessary to cover the command area for adequate water supply.

\section{General Layout of the System}

This water supply project serves the ward no. 8 \& 9 completely and serves ward no. 7 partially of Dhankuta Municipality. The general layout of the Dhankuta 7, 8, 9 water supply system is shown in figure 1 .

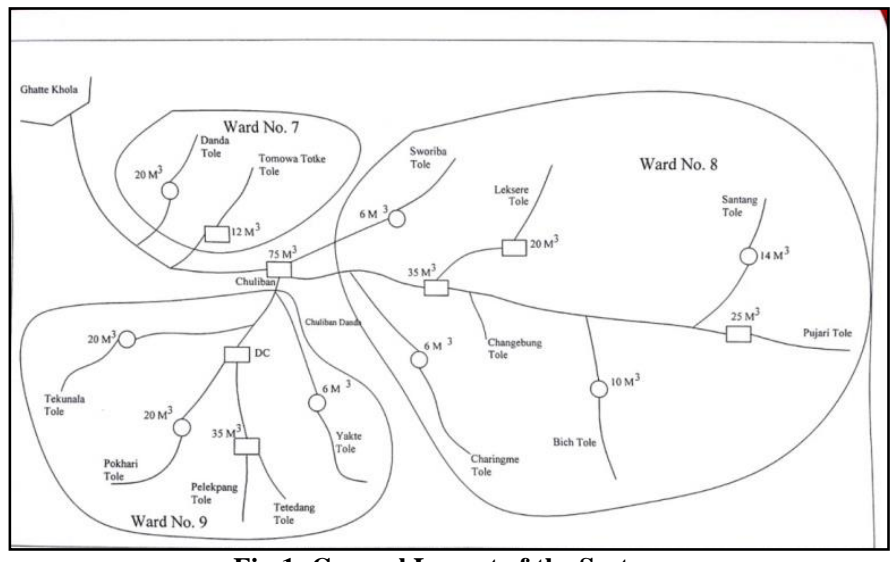

Fig-1: General Layout of the System

The single stream source namely Ghatte Khola is being used as source of water supply. The system is gravity flow design. The water supply system covers the Danda Tole, Tomowa Totke Tole of ward no 7. The system covers the sworiba, leksere, Changebung, Charingme, Changebung, Bich, Santang and Pujari Tole of ward no.8. Similarly Tekunala, Pokhari, Pelekpang,
Tetedang Tole of ward no.9 is covered by this water supply system.

\section{Service Area and Population Served}

The project service area of ward no. 7, 8 and 9 with cluster name including household, population, private taps and community taps are shown in table 1.

Table-1: Service area and population served

\begin{tabular}{|c|c|c|c|c|c|c|c|}
\hline S.No. & Description & Cluster Name & $\begin{array}{c}\text { Present } \\
\text { Household }\end{array}$ & $\begin{array}{c}\text { Sample } \\
\text { Household }\end{array}$ & Population & $\begin{array}{l}\text { No. of } \\
\text { Private } \\
\text { Taps }\end{array}$ & $\begin{array}{c}\text { No. of } \\
\text { Community } \\
\text { Taps } \\
\end{array}$ \\
\hline \multirow[t]{2}{*}{1} & Ward No.7 & Danda Tole & 53 & \multirow[b]{3}{*}{26} & 278 & 53 & \\
\hline & & $\begin{array}{c}\text { Tomowa } \\
\text { Totke }\end{array}$ & 32 & & 173 & 32 & \\
\hline \multicolumn{3}{|c|}{ Sub Total } & 85 & & 451 & 85 & \\
\hline \multirow[t]{7}{*}{2} & Ward No.8 & Sworiba & 6 & \multirow[b]{8}{*}{33} & 34 & 6 & \\
\hline & & Leksere & 22 & & 128 & 22 & \\
\hline & & Santang & 14 & & 77 & 14 & \\
\hline & & Charingme & 8 & & 45 & 8 & \\
\hline & & Chanjebung & 15 & & 85 & 15 & \\
\hline & & Bich & 16 & & 84 & 16 & \\
\hline & & Pujari & 28 & & 146 & 28 & \\
\hline \multicolumn{3}{|c|}{ Sub Total } & 109 & & 599 & 109 & \\
\hline \multirow[t]{5}{*}{3} & Ward No.9 & Tekunala & 20 & \multirow[b]{6}{*}{46} & 249 & & 4 \\
\hline & & Pokhari & 29 & & 158 & 29 & \\
\hline & & Pelekpang & 45 & & 246 & 45 & \\
\hline & & Tetedang & 16 & & 93 & 16 & \\
\hline & & Yakte & 45 & & 114 & & 6 \\
\hline \multicolumn{3}{|c|}{ Sub Total } & 155 & & 860 & 90 & 10 \\
\hline \multicolumn{3}{|c|}{ Total of 7,8 \& 9} & 349 & 105 & 1910 & 284 & 10 \\
\hline
\end{tabular}


The present household of the ward no. 7, ward no. 8 and ward no. 9 are 85,109 and 155 respectively. The total household was 349 and the population is 1910. The sample population from the ward no. $7,8 \&$ 9 are 26, 33 and 46 respectively. The number of private taps in ward no7, ward no. 8 and ward no. 9 are 85,109 and 90 respectively. There are 105 numbers of private taps. $\mathrm{T}$ and there are 10 numbers of public taps in ward no. 9.

\section{Sample size and Technique}

The population of sampling is known and for qualitative versus quantitative study the stratified random sampling method is adopted. The sample size is calculated by using Cocharent formula.

$$
\mathrm{n}=\frac{\mathrm{z}^{2} p q N}{\mathrm{e}^{2}(\mathrm{~N}-1)+\mathrm{z}^{2} \mathrm{pq}}
$$

Where,

$\mathrm{n}=$ Sample size, $\mathrm{Z}=1.96$ for $95 \%$ confidence, $\mathrm{p}=$ percentage of picking choice expressed in decimal (0.5), q=1-p, e=0.08, N= Total Household (349 HH)

From the value $\mathrm{n}$ is calculated as following

$$
\mathrm{n}=\frac{1.96 * 1.96 * 0.5 * 0.5 * 349}{(0.08)^{2} *(349-1)+1.96 * 1.96 * 0.5 * 0.5}
$$

$\mathrm{n}=105$

The coverage area of this water supply project for ward no.7, $8 \& 9$ includes $85,109 \& 155$ households respectively and in total there are 349 household. From the formula the sample size is 105 which are choosen through alternate $3 \mathrm{HH}$ and $4 \mathrm{HH}$ so that there will be representation of beneficiary's household from all clusters, ethnicity, and wards from the service area for interview.

\section{Nature and Source of Data}

The present study is based on both primary and secondary data. The primary data are collected from questionnaires, key informant interview, focus group discussions, field observation.

The secondary data was collected from censuses, information collected by government departments, organizational records, published journals, article, and research paper. The schematic flow chart of water supply project has been drawn from the official documents provided by WSUC and RMSO, Dhankuta.

\section{Primary Data Collection}

To get insight into the research for performance assessment the primary data are collected by following methods.
Key Informant Interview:- The interview was taken with 4 members of WSUC , 2 WSUC staff, 3 staff from RMSO office. The interview was also conducted with 6 consumers of the service area. The KII was done to find out the managerial aspects and, operation and maintenance policies, consumer satisfaction.

Questionnaires: A set of questionnaire regarding institutional aspects was prepared. These questions are focused on performance analysis of Dhankuta 7, 8, 9 water supply systems. The questionnaire which are performed are as follows

- Set I:- Water Supply System Information - 27 Questions for WSUC

- Set II:-Assessment of WSUC Capacity- 30 Questions for WSUC Members

- $\quad$ Set III:- Assessment of WSUC Staff Capacity - 30 Questions for WSUC Staff

- Set IV:- Assessment of Customer Satisfaction - 11 Questions to consumers

- Set V:- Information of Water Supply System - 15 Questions for KII

Focus Group Discussion:- The 3 number of focus group discussion was done in ward no.7 whereas 1 focus group discussion was conducted in ward no. 8 and 3 number of focus group discussion was conducted in ward no. 9 which was fruitful for analysis of functionality status, reliability of water supply service and customer satisfaction.

\section{Water Safety Plan}

The implementation status of water safety plan steps was assessed.

\section{Secondary Data Collection}

Secondary data were collected for a purpose which was relevant and utilized for the research of study of the project. The data were collected from the detailed engineering project design report, published journals, published article, different websites, Government Agencies. The major agencies consulted for collection of secondary data were:

- Central Bureau of Statistics

- Ministry of Water Supply and Sanitation

- Department of Water Supply and Sewerage

- Regional Monitoring and Supervision Office, Dhankuta

- Water Supply and Sanitation Users Committee, Dhankuta

- Dhankuta Municipality

\section{DATA ANALYSIS}

For the analysis, the institutional performance along with implementation status of water safety plan. Based on the response, quantitative as well as qualitative data and information was analyzed. It was presented in tabular form as well in the chart. Other data 
were analyzed qualitatively. The secondary data and information was also included to interpret the analysis.

\section{Institutional Performance Indicator}

Following indicator are analyzed to identify the institutional performance of Dhankuta 7, 8, 9 water supply system.

\section{Functionality Index}

There are some functionality indicators developed by NMIP 2014 for identifying the functional status of water supply projects. The functionality indicators focus on whole year supply, adequate staff including technical and administration \& tools, registration of WSUC, operation and maintenance fund. The researcher has adopted ten indicators including above for determining the current functional index (CFI). Following weightage have assigned to the following ten indicators, the full mark being 100. The CFI has been derived in percentage by the following equation.

Table-2: Calculation of current functionality index

\begin{tabular}{|c|l|l|}
\hline S.No. & \multicolumn{1}{|c|}{ Indicators } & \multicolumn{1}{c|}{ Weightage } \\
\hline 1 & WSUC Registered & Yes (10), No (0) \\
\hline 2 & Having own staffs with maintenance workers & Yes (10), No (0) \\
\hline 3 & O \& M Fund & Sufficient (10), Less (5), No (0) \\
\hline 4 & WSUC Meetings & RegularYes (10), Irregular (5), No (0) \\
\hline 5 & Efficient water tariff collection & Yes (10), Partial (5), No (0) \\
\hline 6 & Record keeping & Proper (10), Random (5), No (0) \\
\hline 7 & Tools and fittings reserve & Sufficient (10), Inadequate (5), No (0) \\
\hline 8 & Water safety plan & Functional (10), Partial Functional (5), Nonfunctional (0) \\
\hline 9 & Reliability (whole year supply) & Yes (10), Nine month (5), Six month (0) \\
\hline 10 & Accessibility & 15 minutes (10), 30 minutes (5), More than 30 minutes (0) \\
\hline Total & & \\
\hline
\end{tabular}

(Source: NMIP, 2014)

\section{Staff Productivity Index}

Staff productivity index is expressed as number of staff per 1000 connections. The higher productive index indicates that there is fewer staff per 1000 connections and the lesser productive index

\section{Staff productivity ratio $=$}

\section{Individual Capacity of WSUC Members}

For the assessment of individual capacity of WSUC member 10 questionnaire of each category are prepared covering different aspects of institutional management, financial management and technical knowledge of WSUC members. The criteria for scoring 0 are bad, 1 to 5 is satisfactory and 6 to 10 is good. Overall assessment of each category was carried out and the result is compiled for analysis.

\section{Individual Capacity of WSUC Staff}

For the assessment of individual capacity of WSUC member 10 questionnaire of each category are prepared covering different aspects of water quality knowledge, office management and technical knowledge of WSUC staff. The criteria for scoring 0 is bad, 1 to 5 is satisfactory and 6 to 10 is good.Overall assessment of each category was carried out and the result are compiled for analysis. Overall assessment of each category is carried out and the result is compiled for analysis. indicates that there is more staff per 1000 connections. The fewer staff per 1000 connections is an important measure of the efficient use of human resource in a utility.

(Number of utility staff)

Number of utility connection (1000)

\section{Implementation Status of Water Safety Plan}

Water safety plan ensures that the delivered water is safe for drinking. WSP is also a proactive effort to reduce risks and prevent contamination before water reaches to the consumers. Water safety plan has been implemented in 2015 in Dhankuta water supply system. The implementation status of water safety plan was analyzed in terms of WSP team formation, system assessment, control measures and survey for customer satisfaction. The sample population for consumer satisfaction survey is 105 which were 26,33 and 46 from ward no.7, ward no. 8 and ward no. 9 respectively.

\section{RESULTS AND DISCUSSION Institutional Performance}

Performance of system depends upon capability of its institution. Capability of a system could be accessed through functionality status, institutional setup and its staff productivity. 


\section{Functionality Status}

The functionality status of the water supply system is checked through functionality index.

Table-3: Calculation of Functionality Index

\begin{tabular}{|c|l|c|c|}
\hline S.No. & \multicolumn{1}{|c|}{ Indicators } & $\begin{array}{c}\text { Marks } \\
\text { Obtained }\end{array}$ & Status \\
\hline 1 & WSUC Registered & 10 & Yes \\
\hline 2 & Having own staffs with maintenance workers & 10 & Yes \\
\hline 3 & O \& M Fund & 5 & Less \\
\hline 4 & WSUC Meetings & 10 & Regular \\
\hline 5 & Efficient water tariff collection & 5 & Partial \\
\hline 6 & Record keeping & 10 & Proper \\
\hline 7 & Tools and fittings reserve & 0 & No \\
\hline 8 & Water safety plan & 5 & Partial Functional \\
\hline 9 & Reliability (whole year supply ) & 5 & Partial \\
\hline 10 & Accessibility & 10 & 15 minutes \\
\hline Total & & $\mathbf{7 0}$ & \\
\hline
\end{tabular}

Current Functionality Index $(\mathrm{CFI})=70 \%$

The Dhankuta 7, 8, 9 water supply project is registered under district water resource committee, Dhankuta. The project has 7 numbers of staff for its operation. The project consists of less amount of fund for its major maintenance work. The WSUC conduct regular meeting. The water tariff seems to be inefficient and there is insufficient tools and fittings for maintenance work. The record keeping is in proper condition. There is lack of tools and fitting reserve for maintenance. The water safety plan has been launched in this project since 2072 Jestha but it is functioning partially. This project serves whole year and the water supply service is accessible within 15 minutes. The calculation shows that the project is running with functional status at present with $70 \%$ CFI. It was found that the system is reliable as it has been providing water throughout the year but according to FGD and KII the consumer was dissatisfied with the supplying pattern of water without proper timing of that $6 \mathrm{hrs}$ supply in a day.

\section{Institutional Setup}

As per statue of Dhankuta 7, 8, 9 WSUC general assembly should be done once in year. From the 100 general member of each ward $10 \%$ member are considered as representative member for general assembly. If it counts 0.5 then it is considered as 1 member. While selection of member representative 33\% of women is compulsory. Before the general assembly ward assembly should be done. Participation of $51 \%$ member representative is compulsory for decision from general assembly. If $25 \%$ of the member representative give written request for call of general assembly then within 15 days it should be done. The tenure of WSUC is 4 years. The memorandum has been found to be followed by WSUC. The latest general assembly was held in 14 May 2016.

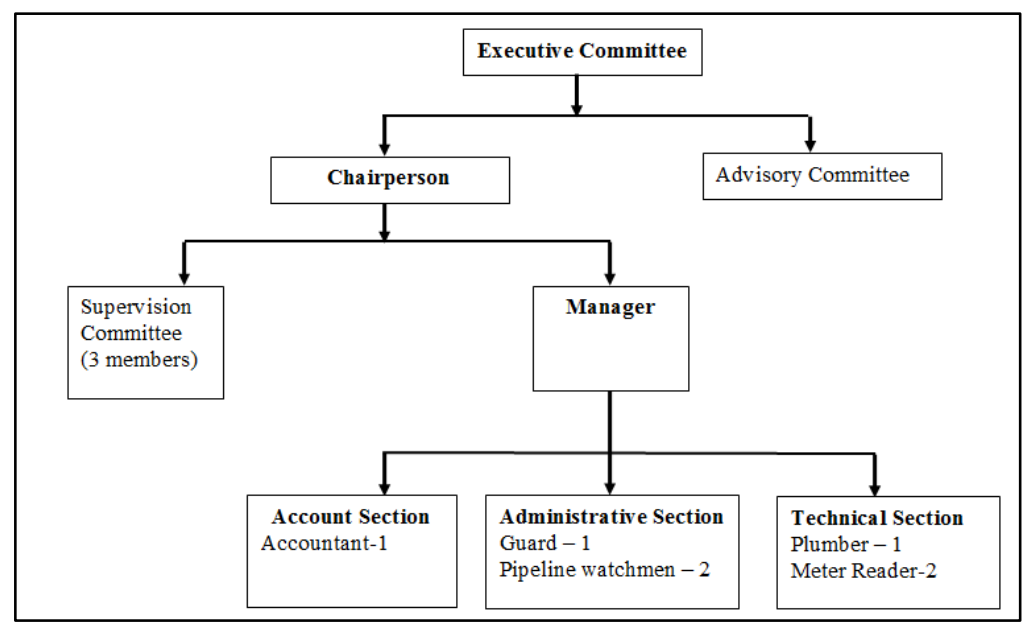

Fig-2: Institutional setup

The Dhankuta 7,8,9 WSUC has been registered on 2014 as per Water Resource Act 1992 and Water Resource Regulation 1993 in district water resource committee of Dhankuta district. The water supply users committee consists of 7 members. The advisory committee consists of single members. Among the 
executive committee only 2 members are female representing $29 \%$ female eventhough the provision is $33 \%$. The WSUC is headed by chairperson. There are 8 member team of employees headed by a manager including technical, financial, administrative and supporting staff. The chairperson has overall responsibility of management of staff, coordination with executive committee as well as for efficient service delivery.

\section{Staff Productivity Index}

The staff productivity index is expressed as number of staff per 1000 connections. The higher productive index indicates that there is fewer staff per 1000 connections and the lesser productive index indicates that there is more staff per 1000 connections. The fewer staff per 1000 connections is an important measure of the efficient use of human resource in a utility.

Table-4: Staff Productivity Index

\begin{tabular}{|c|c|c|}
\hline Year & $\mathbf{2 1 0 1 3 / 1 4}$ & $\mathbf{2 0 1 4} / \mathbf{1 5}$ \\
\hline No. of Staff & 2 & 3 \\
\hline No. of Connection & 261 & 284 \\
\hline Staff Productivity Index & 7.66 & 10.56 \\
\hline
\end{tabular}

The number of staff is 2 and number of connections were 261 in 2013/14 whereas the number of connection is 284 with 3 staffs in 2014/15.The staff productivity index of WSUC in 2013/14 and 2014/15 is 7.66 and 10.56 respectively. The national average of staff productivity index is 7.2. The increase in SPI indicates that the more staff is needed for 1000 connection in that system than national average resulting lesser productivity. The efficient use of human resource is one of the major tasks of WSUC. The staff needs to be well trained, motivated for work. During FGD it was found that the staff does not come in time for maintenance work and the supply of water is not uniform. During discussion with WSUC staff their perception was that demand cannot be fulfilled due to unavailability of water and they have to manage the available water for uniform distribution.

\section{Individual Capacity of WSUC Members}

The result obtained from the survey of individual capacity of WSUC members on the institutional, technical and financial management is compiled and analyzed which is shown in fig 3 .

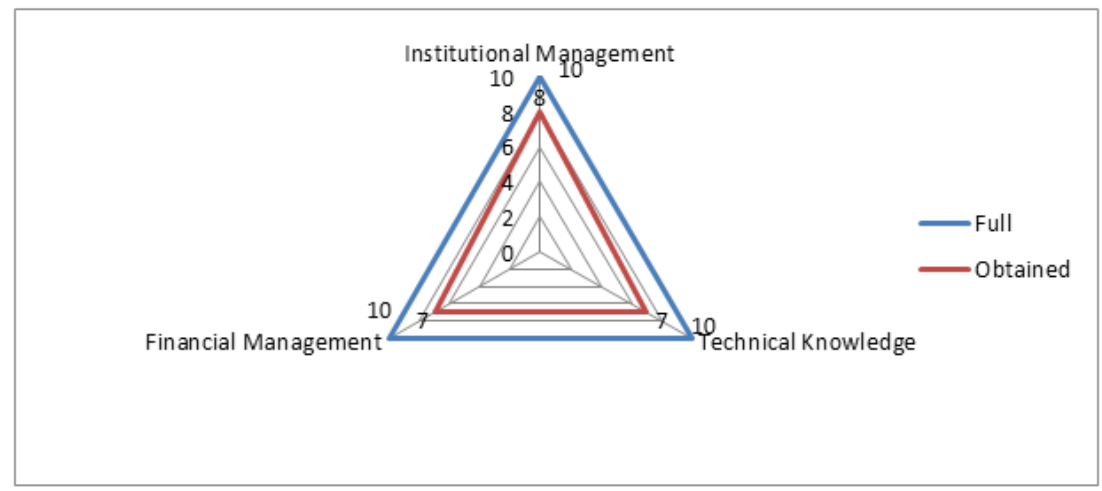

Fig-3: Overall Capacity of WSUC Members

The institutional management scores 8 in weighted score 1 to 10 which shows that the institutional management seems good. The technical knowledge and financial management both scores 7 as good. The capacity of water supply users committee in terms of technical as well as financial management should be enhanced for effective performance. During FGD and KII it was noted that the WSUC still lags management skill for $\mathrm{O} \& \mathrm{M}$ as the consumer are not getting water timely so the capacity of WSUC member should be enhanced for running the water supply system efficiently.

\section{Individual Capacity of WSUC Staff}

The results of survey conducted for the assessment of individual capacity on water quality knowledge, office management and technical knowledge are compiled and analyzed which is shown below. 


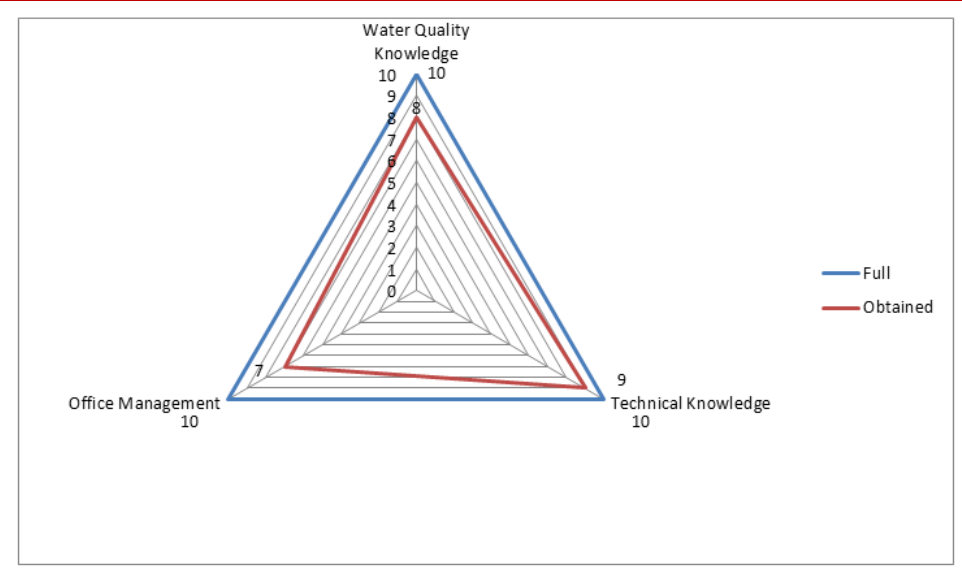

Fig-4: Overall Capacity of WSUC Staff

The water quality knowledge scores 8 out of 10 which show that they have good knowledge in water quality. The technical knowledge score 9 and office management score 7 out of 10 which shows that they are good in technical knowledge as well but the management skill should be enhanced to increase the efficiency. The staff is the major human resource that operates the water supply system effectively so the overall capacity needs to be enhanced to increase the performance of staff. During FGD there is complaining on staff technical skill for maintenance and their willingness to serve promptly as complained by them. As per staff perception it was found that the management of water distribution is difficult due to less reserve of water in distribution reservoirs. The training would enhance the capacity and water availability in the system would motivate the staff for smooth running of water supply system.

\section{Implementation Status of Water Safety Plan}

The water safety plan team consists of 5 members including representative from consumers, WSUC, water supply technician, school teacher. The WSP team has visited the water supply projects from catchment of intake to the consumers tap and household and the clear map of the system has been prepared. The hazard points have been identified in the system (Intake, transmission line, Reservoirs, distribution line). The control measures have been identified and the detail estimate report for the measures was prepared. Due to the limited availability of budget only the intake and transmission line has been maintained but still the reservoir tanks and the distribution line has not been maintained. The water test report shows that there is fecal coliform in the water supply. Stream intake is used as major source for water supply without treatment facilities. During the household survey for customer satisfaction the following results were found.

Table-5: Status of Consumer Satisfaction

\begin{tabular}{|c|c|c|c|c|c|c|}
\hline \multirow[t]{2}{*}{ S.No. } & \multirow[t]{2}{*}{ Questionnaire } & \multicolumn{2}{|c|}{ In Percentage $(\%)$} & & \multirow{2}{*}{\multicolumn{2}{|c|}{ Remarks }} \\
\hline & & Yes & No & & & \\
\hline 1 & Knowledge on importance of water & 79.05 & 20.95 & \multirow{6}{*}{ Ward $7:-26$} & \multirow{6}{*}{$\begin{array}{l}\text { Ward } 8:-33 \\
\quad 46\end{array}$} & \multirow{6}{*}{ Ward 9 :- } \\
\hline 2 & Status of water from intake to tap & 39.05 & 60.95 & & & \\
\hline 3 & Problem solved by WSUC as per complain & 42.86 & 57.14 & & & \\
\hline 4 & Satisfaction with Tariff rate & 43.81 & 56.19 & & & \\
\hline 5 & Satisfaction with repair and maintenance & 38.10 & 61.90 & & & \\
\hline 6 & Alternative source for drinking water & & 100 & & & \\
\hline
\end{tabular}

For the identification of consumer satisfaction the questionnaire was prepared and the 105 people were surveyed. The consciousness about quality of water for public health among the consumer was $79.05 \%$. More than $60 \%$ consumer thought that the water from intake to tap was not safe. $57 \%$ of the consumer was not satisfied with the service providers for solving the problem explained by them immediately. The consumers who were not satisfied with water tariff rate were more than $56 \%$ due to irregularity in supply of water. More than $61 \%$ consumer was not satisfied with repair and maintenance work due to leakage in reservoir, exposure of distribution line. The entire respondent consumer do not have alternative source of water except this system. It was found that the practice of water consumption management was very good even though the demand was not fulfilled with $6 \mathrm{hrs}$ of supply time $3 \mathrm{hr}$ in morning and $3 \mathrm{hr}$ in evening. Thus the improvement of performance of this system was utmost necessary. 
Anjay Kumar Mishra; Saudi J Bus Manag Stud, Sep 2019; 4(9): 698-707

Table-6: Method of $\mathrm{HH}$ Purification of Water

\begin{tabular}{|c|l|c|c|}
\hline S.No. & \multicolumn{1}{|c|}{ Method of treatment } & In Percentage (\%) & \multicolumn{1}{|}{ Remarks } \\
\hline 1 & Directly & 34.29 & \multirow{4}{*}{ Ward 7 :- 26 Ward 8 :- 33 Ward 9 :- 46 } \\
\hline 2 & Boiling water & 52.38 & \\
\hline 3 & Chlorination & 0 & \\
\hline 4 & Filter & 13.33 & \\
\hline 5 & Solar Water Disinfection (SODIS) & 0 & \\
\hline
\end{tabular}

The consumer who drinks water directly was $34 \%$ whereas more than $52 \%$ cosumer drink water after boiling. Only $13.33 \%$ of consumer uses filter. The chlorination and SODIS was not found popular on the service area. During FGD and KII it was found the consciousness on water quality was found that the first priority of improvement was distribution of water from treatment plant which needs to be constructed and there the awareness on household water treatment method should be conducted.

\section{Following are the findings of the study}

- The functionality index was found $70 \%$ which indicates that the system was not functioning properly.

- The staff productivity index is 36.53 that show the lesser staff productivity.

- The individual capacity of WSUC member obtains 8 out of 10 in institutional management whereas in technical knowledge and financial management both score 7 resulting in need of capacity enhancement.

- The score obtained by WSUC staff in water quality knowledge, technical knowledge and office management are $8,9 \& 7$ respectively out of 10 resulting in need of skill development.

- The implementation status of water safety plan is partial functional and the consumer satisfaction survey shows that the consumers are conscious about water quality and more than $50 \%$ prefer boiling before drinking water.

\section{CONCLUSIONS}

The institutional performance of water supply system is not satisfactory eventhouh there are some positive points such as inclusive approach for formation of WSUC, timely meeting, general assembly, audit but despite of this the staff productive index is high in comparison to national average, unable to collect the revenue on time, dissatisfaction of consumer on water supply service as well as performance of staff. The implementation status of water safety plan is very weak due to partially functional.

\section{REFERENCES}

1. Mishra, A. K., \& Acharya, S. R. (2018). Performance assessment of Salyankot water supply project in post-earthquake scenario of Nepal. Journal of Advanced Research in Geo Sciences \& Remote Sensing, 5(3\&4), 23-40.

2. Mishra, A. K., \& Shrestha, M. (2017). Health and safety status of casual workers in road improvement project Kathmandu Valley, Nepal. International Journal of Engineering Technology Science and Research (IJETSR), 4(9), 1187-1199.

3. Mishra, A.K., (2018). International Journal of Operations Management and Information Technology. 8(1). 1-30 (C) Research India Publications http://www.ripublication.com

4. Danilenko, A., Berg C., Macheve, B., Moffitt, L.J. (2014). The IBNET Water Supply and Sanitation Blue Book. 2014. Available at: https://openknowledge.worldbank.org/bitstream/ha ndle/10986/19811/9781464802768.pdf. [Accessed 28 September 2014].

5. Brikke, F., Water, S., Supply, W., Network, M., \& World Health Organization. (2000). Operation and maintenance of rural water supply and sanitation systems: a training package for managers and planners (No. WHO/SDE/WSH/00.2). Geneva: World Health Organization.

6. WELL., \& Great Britain. Dept. for International Development. (1998). Guidance manual on water supply and sanitation programmes. WEDC, Loughborough University.

7. Otoo, S., Agapitova, N., \& Behrens, J. (2009). The capacity development results framework.

8. WB. (2012). Guide to Evaluating Capacity Development Results, [Online]. Available at: https://wbi.worldbank.org/wbi/Data/wbi/wbicms/fil es/drupal-

acquia/wbi/Guide\%20to\%20Evaluating\%20Capacit y\%20Development\%20Results_0.pdf. [Accessed 28 September 2014].

9. Mishra, A. K. (2018). Sustainability and risk assessment of Salyankot water supply project in post-earthquake scenario. International Journal of Operations Management and Information Technology, 8(1), 1-30. 